\title{
The mediating effect of humour in relation to early maladaptive schema domains and psychological wellbeing
}

\author{
Erken dönem uyumsuz şema alanları ve psikolojik iyi oluş hali arasındaki \\ ilişkide mizahın aracı rolü
}

Burak Baran Yavuz' ${ }^{1}$, Başak Türküler Aka²

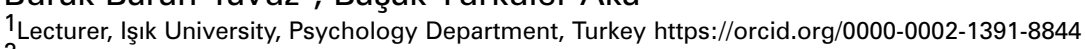

${ }^{2}$ Assis. Prof., Bahçeşehir University, Psychology Department, Turkey https://orcid.org/0000-0002-5330-8485

SUMMARY

Objective: Early Maladaptive Schemas may accompany and affect different areas of life and may cause psychological problems. Therefore, psychological wellbeing may get affected negatively. Individuals prefer different ways to cope with stress caused by schemas and humour is a common method that has been used since the very early ages of humanity. Recent study examines the mediational effect of humour in relation to early maladaptive schemas and psychological wellbeing. Method: 268 individuals (181 female, 87 male) between the ages of 17 and $67(M=29.09, S D=9.58)$ participated in the current study and the data were collected online. The study measures were Young Schema Questionnaire (YSQ), The Humor Styles Questionnaire (HSQ) and the Warwick-Edinburgh Mental Well-Being Scale (WEMWBS). Results: Correlation analyses showed that psychological wellbeing negatively associated with maladaptive humour styles, and positively associated with adaptive humour styles. Only impaired autonomy and disconnection schema domains were found in association with psychological wellbeing, both negatively. Results of the bootstrap mediation indicated that aggressive humour mediates the relationship between impaired autonomy domain and psychological wellbeing, self-enhancing humour mediates the relationship between disconnection, impaired autonomy, impaired limits and psychological wellbeing. Lastly, self-defeating humour mediated the relationship between other-directedness, unrelenting standards and psychological wellbeing. Discussion: The results indicated that humour has a mediating role in the relationship between schema domains and psychological wellbeing. Specifically, it was discussed that the mediational roles of self-enhancing, self-defeating and aggressive humour might allow the therapists to intervene subtle mediums of self-harm (i.e. maladaptive humour) or strengthen the self-help (i.e. adaptive humour) and enhance psychological wellbeing.

\section{ÖZET}

Amaç: Erken dönem olumsuz şemalar, bireylerin farklı yaşam alanlarını etkileyerek çeşitli ruhsal bozukluklara sebep olabilmekte ve iyi-oluş halini etkilemektedir. İyioluş hali olumsuz etkilendiğinde bireyler daha iyi hissetmek için farklı başa çıkma yöntemleri kullanmayı tercih edebilirler. Yaygın olarak kullanılan başa çıkma yöntemlerinden biri de mizahtır. Bu araştırma mizah kullanımının erken dönem olumsuz şemalar ve psikolojik iyi-oluş arasındaki aracı ilişkisini incelemektedir. Yöntem: Araştırmaya 17 - 67 yaşları arasında (Ort $=29.09$, SS $=$ 9.58) yer alan 268 birey katılmıştır (181 kadın, 87 erkek). Araştırma verileri çevrimiçi olarak toplanmıştır. Veri toplama araçları olarak Young Şema Ölçeği (YŞÖ), Mizah Tarzları Ölçeği (MTÖ) ve Warwick-Edinburgh Mental ìyi Oluş Ölçeği (WEMiOÖ) kullanılmıştır. Bulgular: Korelasyon analizleri iyi-oluş halinin, uyumlu mizah tipleri ile pozitif, uyumsuz mizah tipleri ile negatif ilişkili olduğunu, kopukluk ve zedelenmiş otonomi şema alanlarıyla negatif ilişkili olduğunu göstermiştir. Aracı değişken analizleri ise saldırgan mizahın zedelenmiş otonomi ve iyi-oluş hali arasında; kendini geliştirici mizahın kopukluk, zedelenmiş otonomi, zedelenmiş sınırlar ve iyi-oluş arasında aracı rolü olduğunu göstermiştir. Ayrıca, kendini-yıkıcı mizahın diğer-yönelimlilik, yüksek standartlar ve iyi-oluş hali arasında aracı etkisi olduğu da görülmüştür. Sonuç: Mizah kullanım tarzının, şemalar ve iyi-oluş arasındaki ilişkide aracı bir rolünün olduğu bulunmuştur. Özellikle, kendini geliştirici, kendini yıkıcı ve saldırgan mizahın aracı rolü değerlendirildiğinde, klinik çalışmalarda uyumsal olmayan mizah biçimlerine müdahale edilebileceği ve uyumsal mizahın güçlendirilerek iyi-oluş haline katkıda bulunulabileceği düşünülmüştür.

Anahtar Sözcükler: Erken dönem olumsuz şemalar, mizah tarzları, iyi-oluş hali

Key Words: Early maladaptive schemas, humour styles, psychological wellbeing

(Turkish J Clinical Psychiatry 2021;24:288-297)

DOI: $10.5505 / \mathrm{kpd} .2021 .21548$ 


\section{INTRODUCTION}

Beck et al. (1) stated that the self-concepts of individuals consist of attitudes about themselves and their world. They mentioned that these concepts can be acquired from others' judgments on them, identifications from influential figures (e.g. mother, father, siblings) and early experiences. These selfconcepts become structuralized in time and turn into a cognitive structure or a schema.

Chronic psychological problems, personality disorders and other debilitating issues might have been stemmed from early maladaptive schemas (EMS) $(2,3)$. Young $(2,3)$ suggested that toxic childhood experiences, emotional temperament and unsatisfied core emotions might be the originating factors of EMSs. Young et al. (4) state five schema domains that specifically drawn from five core needs of children and eighteen schemas that have unique schema coping behaviours and styles. Disconnection (D) schema domain is primarily based on emotional needs, their absence or oversaturation. Individuals with this domain related schemas tend to conceive themselves as unlovable, unwanted or inferior $(5,6)$ and they usually act in a self-destructive way to avoid or terminate intimate relationships (4). Impaired Autonomy (IA) schema domain characterized by negative presumptions of capabilities. Young et al. (4) defined autonomy as the ability to differentiate one from his/her parents or family and live independently, in line with Bowlby (7), as responsive caregiver's (i.e. parent) encouragement of the children to explore the environment is necessary. Overprotective or neglecting/inattentive families might influence the development of this domain's schemas. Impaired limits (IL) domain schemas consist of self-control and others' rights themed problems. Young et al. (4) stated that these schema bearers are sometimes criticized by others for being ego-centric, entitled or grandiose; schemas of this domain might have been originated from early reinforcements, instead of giving proper reactions, of rule bending behaviours. Other-directedness (OD) domain conceived to be related to conditional acceptance and care provided by caregivers. Young et al. (4) stated that during childhood, individuals with this schema might have learned that to satisfy their own needs they have to please the others first. Especially, self- sacrificing patterns were found to be trans-generational; one study stated that fathers with that cognitive structure transfer their schema to their daughters (8). Over-vigilance and inhibition schema domain refers to the suppression of spontaneous emotions and urges. Young et al. (4) argued that the discouragement of spontaneity and playfulness might facilitate the development of pertinent schemas. Individuals with this domain related schemas usually perform in parallel to their internalized rules or standards and tend to do not feel remorse for losing their happiness, self-voice, comfort, close relationships and health. In the Turkish adaptation study, this schema domain was altered and renamed as unrelenting standards (US). Soygüt et al. (9) stated that there are 5 schema domains, in line with Young (10), in which encompass fourteen early maladaptive schemas and some schemas. In the present study, the associations sought in parallel with the Turkish adaptation study's domains.

Early maladaptive schemas may present themselves in different forms such as behaviours, cognitions and emotions (11); along with that schema coping styles might present themselves in other forms, as well. Dozois et al. (12) argued that humour may substitute some expressions in which individuals might use them as schema coping behaviours. They hypothesized that individuals (e.g. emotional inhibition) might give the impression of being flat, affectless individuals. In other schemas which are pertinent with disconnection (i.e. emotional deprivation, mistrust/abuse, social isolation/alienation), individuals with that schemas may not develop or acquire a friendly environment in which they share a fun time with others. As a result of that these individuals might prefer to use humour in a more cynical, critical or avoidant style. When humour used in this way, one might drive others away and may experience negative emotions and become a loner. Dozois et al. (12) stated that the reciprocal use of humour can be contemplated as Young's (3) schema coping styles. On the other hand, adaptive usage of humour may as well affect the schema's influence on negative emotions. They proposed that the style of humour might mediate the association between EMS domains and depression severity. Later, they also found similar effects of humour usage on the relationship between EMS 
domains and aggression/anger (13).

Humour is a unique way for human interaction (14). Humour, both in negative and positive ways, can be used for different objectives. Individuals can use humour to create new relationships, empower or maintain bonds or even manipulate others to reach their goals (14). Martin et al. (15) proposed four factors that define humour styles operating in expressed, internal, adaptive and maladaptive ways. These humour styles are affiliative, aggressive, self-enhancing and self-defeating humour.

Martin et al. (15) stated that if the usage of humour aims to solve or endure life problems and exercised in an internal way it is named as self-enhancing humour. This style of humour is thought to be effective at dealing with negative emotions and altering perspectives on problematic incidents that might negatively affect the individual. Increased use of this style linked with agreeableness, openness to experience and self-esteem (16). In marital life, it was found that marital satisfaction is positively associated with self-enhancing type humour usage (17). If the humour occurs in an interpersonal context and is adaptive, then it is referred to as affiliative humour. This type of humour is used as a medium of creating bonds and initiate interactions via jokes and funny statements about one's self or others within limits of personal respect and genuineness (15). Affiliative (also known as social humour, 14) humour is linked with agreeableness, openness to experience and self-esteem (16). Dozois et al. (12) stated that affiliative humour mediates the relationship between disconnection schema domain and depression. Some people use humour to make others happy however they might reduce their self-worth and self-esteem in the long run. Martin et al. (15) referred to this type of humour as self-defeating humour and self-defeating humour was negatively associated with emotional stability, conscientiousness, attachment security and self-esteem (16). Saroglou et al. (17) found that increased use of self-defeating humour linked with low levels of marital satisfaction and divorce rate. Dozois et al. (13) stated that self-defeating humour has a mediational effect in the relationship between aggression/hostility and impaired limits, disconnection/rejection, impaired autonomy domains. Moreover, in Dozois et al.'s (12) study they stated that self-defeating humour can mediate the relationship between schemas of exaggerated standards, impaired limits and depression severity. Aggressive humour refers to the use of humour in a maladaptive way at social situations. Individuals use this type of humour to boost their sense of superiority; they often oppress, criticize, ridicule and humiliate the other (15). Aggressive humour was associated with lower levels of agreeableness and conscientiousness (16). Saroglou (18) stated that religious people often do not tend to use this type of humour. Dozois et al. (13) argued that this humour style mediates the link between impaired limits schema domain and aggression.

In line with the previous studies, humour is considered as coping style behaviour in the current study $(12,13)$. Psychological wellbeing encompasses both abnormal and subjectively normal dimensions of human mental life and includes intra- and interpersonal interactions (19).

To the knowledge of the authors, no other studies have investigated the relationship between humour styles, maladaptive schema domains, and psychological wellbeing. Since humour is a part of daily and social life, investigating its possible working mechanisms and getting a clue about its effects will be an important contribution both to the literature and therapy practice as a coping style. The present study explores the mediational effects of humour styles in relation to early maladaptive schema domains and psychological wellbeing. We hypothesized that the relationship between EMS domains and psychological wellbeing can be mediated by humour styles. We expect to find that negative effects of EMS domains will be mediated by lower levels of adaptive humour (i.e. self-enhancing and affiliative humour) along with higher levels of maladaptive humour (i.e. self-defeating and aggressive humour) use and psychological wellbeing.

\section{Participants}

A total of two hundred and sixty-eight individuals participated in the study (67.5\% female). The sample size was not predetermined with reference to effect size. The participants' ages ranged between 17 and $67(\mathrm{M}=29.09, \mathrm{SD}=9.58)$ Two 
(.7\%) participants had primary school education, $21(7.8 \%)$ participants had high school education, $39(14.6 \%)$ participants had associate's degree, 138 $(51.5 \%)$ participants had bachelor's degree, 59 (22\%) participants had master's degree and 9 (3.4\%) participants had PhD degree.

\section{Measures}

The Young Schema Questionnaire-Short Form (YSQ-SF) $(2,3)$ has 90-items and it assesses 18 EMSs that can be classified into five domains; Impaired Autonomy, Disconnection and Rejection, Unrelenting Standards, Impaired Limits and Other-Directedness. The Turkish adaptation study revealed adequate internal consistency for schema domains ranging from .53 to .81 (9). In the current study, the Cronbach alpha coefficients range from .66 (Impaired Limits) to .92 (Impaired Autonomy), with a total scale a coefficient of .95 .

The Humour Styles Questionnaire (HSQ) has 32 items and higher values in the scale reflect higher use of the specific humour styles (15). The Turkish form was adapted by Yerlikaya (20), and it has four factors representing four Humour Styles as affiliative $(a=.74)$, self-enhancing $(a=.78)$, self-defeating $(\mathrm{a}=.67)$ and aggressive humour $(\mathrm{a}=.69)$, respectively. In the current study, the Cronbach alpha coefficients range from .69 (Aggressive Humour) to .81 (Self-Enhancing Humour), with a total scale alpha coefficient of .79 .

The Warwick-Edinburgh Mental Well-Being Scale (WEMWBS) includes 14 items and higher values reflect higher levels of psychological wellbeing (19). The scale was adapted to Turkish by Keldal (21), it had very high internal reliability, .92. In this study, the Cronbach alpha coefficient was .90.

\section{Procedure}

Ethical approval for the data was granted by the Bahçeşehir University Scientific Research and Publications Ethics Committee. The data were collected online via a form supported by Google Forms service (https://docs.google.com/forms). The link for the study was advertised throughout social media like Instagram and Facebook by using convenience sampling method. The completion of the study measures approximately took twenty minutes. The data were collected between 2017 January - February.

\section{RESULTS}

\section{Data Analytic Strategy}

Mediation analyses were performed using IBM SPSS Statistics for Macintosh, Version 25.0 (IBM Corp, Armonk, NY) via Hayes' (2019) PROCESS procedure for SPSS (Release 3.4). In these mediation analyses, it was tested whether humour styles (i.e., scores on the HSQ) mediate the link between five EMS domains (i.e., scores on the YSQ-SF) and psychological wellbeing (i.e., scores on the WEMWBS). Moreover, age and gender were included in the mediation analyses as covariates as they are significantly correlated with the study variables.

Mean effects and confidence intervals were estimated applying Hayes' (22) bootstrapping procedure with 5,000 resamples. For confidence intervals, to conclude for mediation, the assumption that $95 \%$ BC confidence interval must not include zero was accepted (23).

The descriptive statistics of the measures and the correlations among them are reported in Table 1.

\section{Impaired Autonomy Domain (IA)}

The first mediation model included IA domain as the independent variable, the four humour styles (i.e., Affiliative Humour, Aggressive Humour, SelfEnhancing Humour, Self-Defeating Humour) as mediators, and psychological wellbeing as the dependent variable, age and gender as covariates. Results revealed this model (Figure 1) was significant $F(7,260)=26.00, p<0.001, \mathrm{R}^{2}=.41$.

In terms of mediation, IA domain had a significant indirect effect on Psychological Wellbeing only through Self-Enhancing Humour $(\beta=-.06, \mathrm{SE}=$ $.02,95 \%$ BCa CI $[-0.10,-0.03])$ and Aggressive 
The mediating effect of humour in relation to early maladaptive schema domains and psychological wellbeing

Table 1. Descriptive statistics and correlations between measures

\begin{tabular}{|c|c|c|c|c|c|c|c|c|c|c|c|c|c|c|}
\hline & Mean & SD & 1 & 2 & 3 & 4 & 5 & 6 & 7 & 8 & 9 & 10 & 11 & 12 \\
\hline $1 \mathrm{Sex}$ & & & 1 & & & & & & & & & & & \\
\hline 2 Age & 29.09 & 1.02 & -.04 & 1 & & & & & & & & & & \\
\hline $3 \mathrm{PW}$ & 3.89 & .66 & $\begin{array}{l}.04 \\
\end{array}$ & $.16^{* *}$ & 1 & & & & & & & & & \\
\hline $4 \mathrm{IA}$ & 2.16 & .75 & .08 & $-.13^{*}$ & $-.53 * * *$ & 1 & & & & & & & & \\
\hline $5 \mathrm{D}$ & 2.17 & .86 & $.20 * *$ & $-.21 * *$ & $-.45 * * *$ & $.72 * * *$ & 1 & & & & & & & \\
\hline 6 US & 3.34 & .95 & $.13^{*}$ & -.06 & -.10 & $.37 * * *$ & $.30 * * *$ & 1 & & & & & & \\
\hline $7 \mathrm{IL}$ & 3.72 & .89 & $.18^{* * *}$ & $-26 * * *$ & -.01 & $.17 * *$ & $.26^{* * *}$ & $.36^{* * *}$ & 1 & & & & & \\
\hline $8 \mathrm{OD}$ & 3.40 & .83 & $.19 * *$ & .58 & -.09 & $.46^{* * * *}$ & $.43 * * *$ & $.45 * * *$ & $.25 * * *$ & 1 & & & & \\
\hline $9 \mathrm{AffH}$ & 5.58 & .94 & -.04 & $-.16^{* *}$ & $.25 * * *$ & $-.23 * * *$ & $-.31 * * *$ & -.00 & $.12 *$ & -.10 & 1 & & & \\
\hline $10 \mathrm{AggH}$ & 2.69 & .98 & $.31 * * *$ & $-.24 * * *$ & $-.27 * * *$ & $.18 * *$ & $.20 * *$ & .09 & .05 & -.04 & .03 & 1 & & \\
\hline $11 \mathrm{SdefH}$ & 3.43 & 1.02 & $.16^{* *}$ & -.05 & $-.15^{*}$ & $.31 * * *$ & $.28 * * *$ & $.23 * * *$ & .10 & $.33 * * *$ & .09 & $.27 * * *$ & 1 & \\
\hline $12 \mathrm{SenhH}$ & 4.29 & 1.16 & -.03 & -.09 & $.40 * * *$ & $-.20 * *$ & $-.13^{*}$ & -.05 & $.20 * *$ & -.02 & $.48 * * *$ & -.06 & $.16^{* *}$ & 1 \\
\hline
\end{tabular}

Note. PW: Psychological Wellbeing; IA: Impaired Autonomy; D: Disconnection; US: Unrelenting Standards; IL: Impaired Limits; OD: Other Directedness; AffH: Affiliative Humour; AggH: Aggressive Humour; SdefH: Self-Defeating Humour; SenhH: Self-Enhancing Humour

$* * * p<.001 * * \quad p<.01 * p<.05$

Humour $(\beta=-.02, \mathrm{SE}=.01,95 \%$ BCa CI $[-0.04$, $0.00])$. The presence of both the direct effect of IA on Psychological Wellbeing and indirect effects of Self-Enhancing Humour and Aggressive Humour indicates a complementary mediation (24).

\section{Disconnection Domain (D)}

The second mediation model $\mathrm{D}$ domain as the independent variable, the four humour styles (i.e., Affiliative Humour, Aggressive Humour, SelfEnhancing Humour, Self-Defeating Humour) as mediators, and psychological wellbeing as the dependent variable. Results demonstrated a significant model (Figure 2), $F(7,260)=21.57, p<0.001$, $\mathrm{R}^{2}=.37$.

For mediational results, D domain had a significant indirect effect on Psychological Wellbeing only through Self-Enhancing Humour $(\beta=-.04, \mathrm{SE}=$ $.02,95 \%$ BCa CI $[-0.08,-0.01])$. The presence of both the direct effect of $\mathrm{D}$ on Psychological Wellbeing and the indirect effect of Self-Enhancing Humour indicates a complementary mediation (24).

\section{Unrelenting Standards Domain (US)}

As the third mediation model, US domain was analysed as the independent variable, the four humour styles (i.e., Affiliative Humour, Aggressive Humour, Self-Enhancing Humour, Self-Defeating Humour) as mediators, and psychological wellbeing as the dependent variable. Results revealed this model (Figure 3) was significant, $F(7,260)=14.14$, $p<0.001, \mathrm{R}^{2}=.28$.

In terms of mediation, US domain had a significant indirect effect on Psychological Wellbeing only through Self-Defeating Humour $(\beta=-.03, \mathrm{SE}=.01$, $95 \%$ BCa CI $[-0.05,-0.01])$. The presence of only the indirect effect of Self-Defeating Humour indicates an indirect-only mediation (24).

\section{Other-Directedness Domain (OD)}

In the fourth mediational model, OD domain was taken as the independent variable, the four humour styles (i.e., Affiliative Humour, Aggressive Humour, Self-Enhancing Humour, Self-Defeating Humour) as mediators, and psychological wellbeing as the dependent variable.

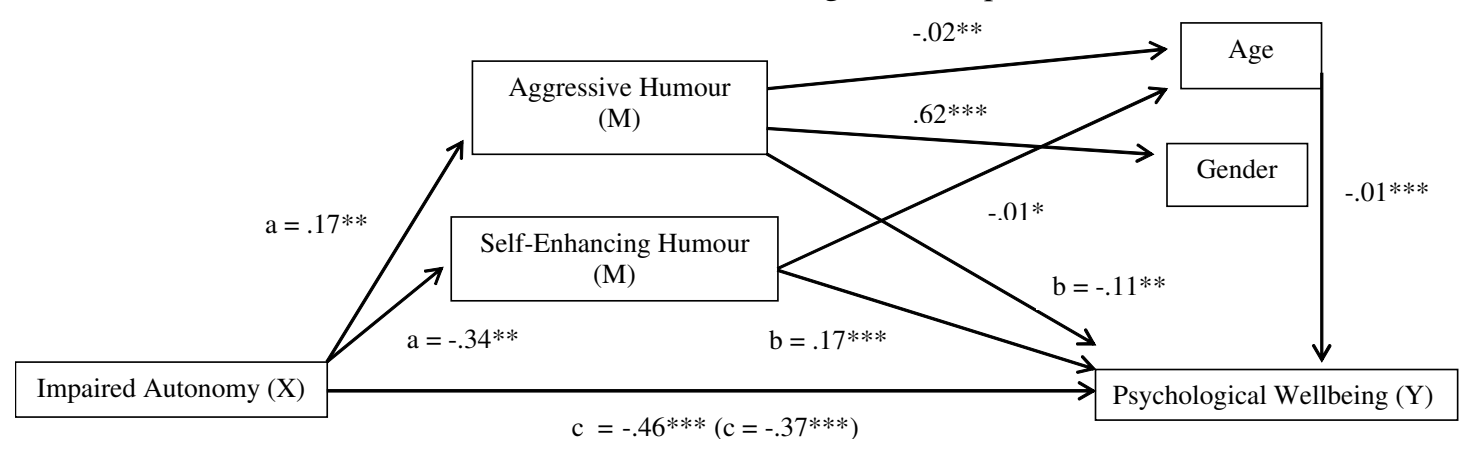

Figure 1. Multiple mediation model of the relationship between Impaired Autonomy, Humour Stlyes and Psychological Wellbeing while being Age and Gender controlled as covariates. Arrows represent associations with the significance levels $\left({ }^{*} p<0.05 ; * *<<0.01 ; * * * p<0.001\right)$. The letters in lowercases represent pathways through predictor to mediator (a), mediator to predicted (b) and predictor to predicted (c for direct effect and c for total effect). 


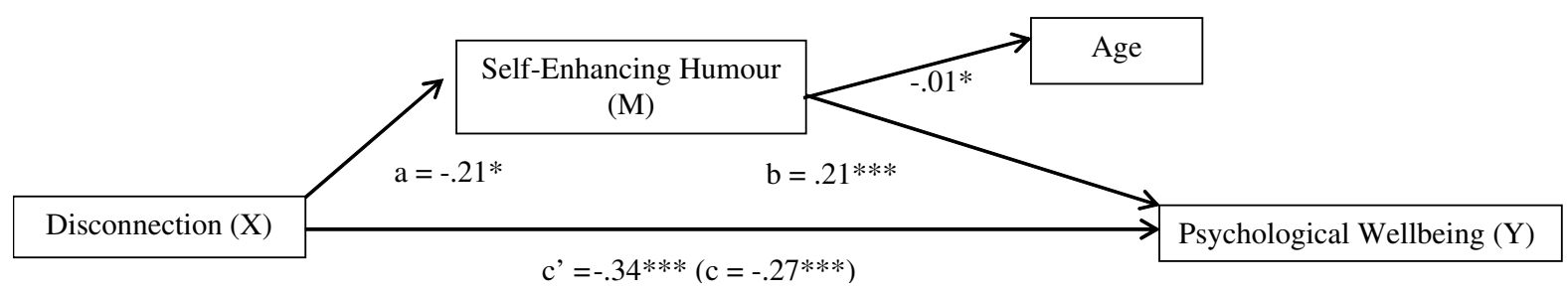

Figure 2. Mediation model of the relationship between Disconnection, Humour Stlyes and Psychological Wellbeing while being Age and Gender controlled as covariates. Arrows represent associations with the significance levels $(* p<0.05 ; * * p$ $<0.01 ; * * p<0.001)$. The letters in lowercases represent pathways through predictor to mediator (a), mediator to predicted (b) and predictor to predicted (c for direct effect and c for total effect).

According to the results, this model (Figure 4) was also significant $F(7,260)=14.23, p<0.001, \mathrm{R}^{2}=$ .28 .

For mediational results, OD domain had a significant indirect effect on Psychological Wellbeing only through Self-Defeating Humour $(\beta=-.04, \mathrm{SE}=.02$, $95 \%$ BCa CI $[-0.08,-0.01])$. The presence of only the indirect effect of Self-Defeating Humour indicates an indirect-only mediation (28).

\section{Impaired-Limits Domain (IL)}

As the last mediational model, IL domain was analysed as the independent variable, the four humour styles (i.e., Affiliative Humour, Aggressive Humour, Self-Enhancing Humour, Self-Defeating Humour) as mediators, and psychological wellbeing as the dependent variable. Results demonstrated a significant model (Figure 5), F(7, 260) =14.25, $\mathrm{p}<0.001, \mathrm{R} 2=.28$.

In terms of mediation, IL domain had a significant indirect effect on Psychological Wellbeing only through Self-Enhancing Humour $(\beta=.06, \mathrm{SE}=.02$,
$95 \%$ BCa CI $[0.02,0.10])$. The presence of only the indirect effect of Self-Enhancing Humour indicates an indirect-only mediation (24).

\section{DISCUSSION}

Psychological wellbeing is an important factor in human life; it indicates an increased harmony for the one among the others and facilitates the engagement to genuinely meaningful actions in one's life (19). Previous studies indicate that elevated activation of EMSs might lead to an increase at negative psychological states (4) and humour can be considered as a coping method when dealing with the negativity that emerged by the activation of EMSs $(12,13)$. Furthermore, studies also show that increased use of adaptive use of humour might predict increased psychological wellbeing (25). On the other hand, it was found that maladaptive use of humour might have a negative effect on subjective wellbeing (26). The present study aimed to explore the mediational role of humour in the relationship between EMSs and psychological wellbeing. It was hypothesized that adaptive humour styles would mediate the negative effects of EMSs on psychological wellbeing positively and maladap-

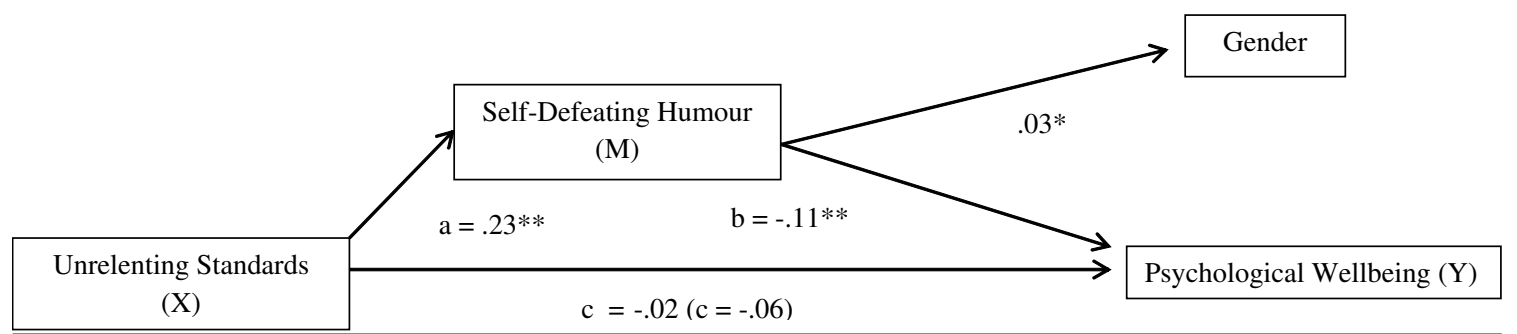

Figure 3. Mediation model of the relationship between Unrelenting Standards, Humour Stlyes and Psychological Wellbeing while being Age and Gender controlled as covariates. Arrows represent associations with the significance levels $(* p<0.05$; $* * p<0.01 ; * * * p<0.001)$. The letters in lowercases represent pathways through predictor to mediator (a), mediator to predicted (b) and predictor to predicted (c for direct effect and c for total effect). 


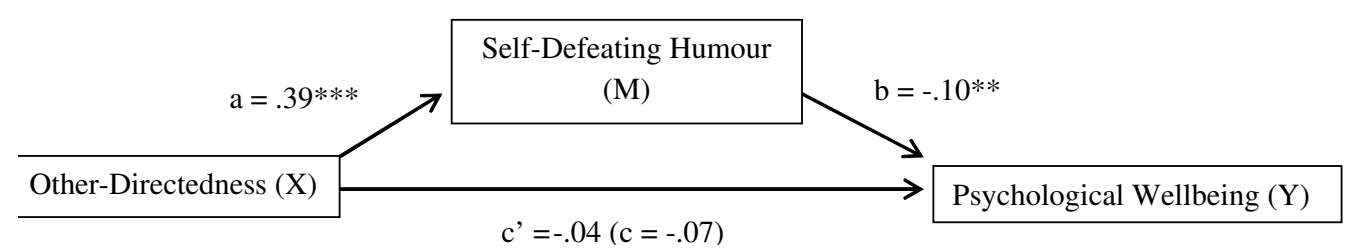

Figure 4. Mediation model of the relationship between Other-Directedness, Humour Stlyes and Psychological Wellbeing while being Age and Gender controlled as covariates. Arrows represent associations with the significance levels $(* p<0.05 ; * *<0.01 ; * * *<0.001)$. The letters in lowercases represent pathways through predictor to mediator (a), mediator to predicted (b) and predictor to predicted (c for direct effect and c for total effect).

tive use of humour would also lead to a more negative state of being in terms of psychological wellbeing in relation to EMSs.

Recent study's correlation analyses showed that IA and D schema domains associated negatively with psychological wellbeing whereas adaptive humour styles correlated positively and maladaptive humour styles correlated negatively. As Young et al. (4) indicate, EMSs might have a negative effect due to their maladaptive qualities and increased severity of a schema might be in line with negative qualities of one's psychological wellbeing which includes inter and intra-personal states of a person. In line with that, as Martin et al. (15) suggest, adaptive humour use can have a positive relationship with psychological wellbeing whereas maladaptive use might associate with a decline of psychological wellbeing.

Furthermore, aggressive humour and self-enhancing humour both mediated the relationship between IA and psychological wellbeing. According to these results, people with dominant IA domain schema activations may have difficulties at coping with problems that they may face because of the decreased sense of self-confidence and competency (4). It is also stated that IA domain schemas are correlated with aggression and anger (27). When these attributional cognitions are activated in a social context, individuals might use aggressive humour to conceal their incompetency related thoughts by attacking others. However, this would follow a negative response from the others, and one may become a loner and, in the end, their lack of self-confidence and thoughts of incompetence would lead to a decrease in psychological wellbeing. In terms of self-enhancing humour, results imply that if self-attributions about lack of self-confidence and incompetency can be handled via humour, and their negative effects can be deflected, one can effectively participate in the social context and may increase his/her usefulness and productivity as the increased psychological wellbeing presumes (19). When the mediation types are taken into account, both compensatory mediations indicate that the mediational role of self-enhancing and aggressive humour does not solely depict the whole mediational paradigm (24). In other words, it can be said that there can be other variables might be affecting the mediational role of aggressive and self-enhancing humour such as verbal intelligence of the person, other coping techniques that the one might use, religious or personal attributes and so on. An explorative study might show prospective mediator.

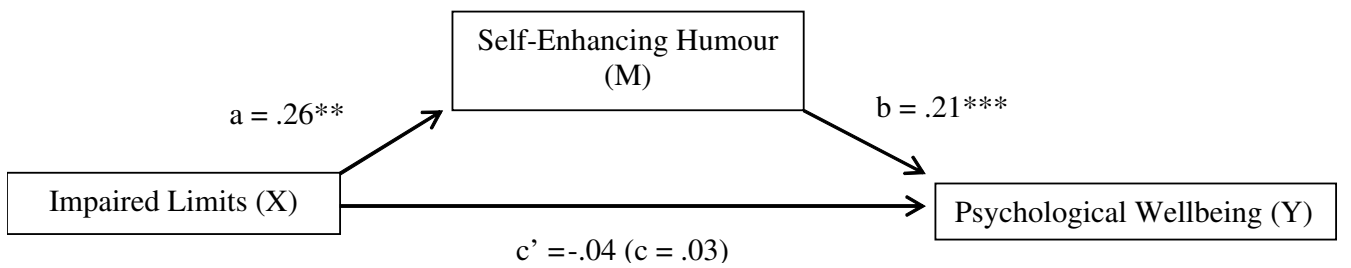

Figure 5. Mediation model of the relationship between Impaired Limits, Humour Stlyes and Psychological Wellbeing while being Age and Gender controlled as covariates. Arrows represent associations with the significance levels $\left({ }^{*} p<\right.$ $0.05 ; * * p<0.01 ; * * *<0.001)$. The letters in lowercases represent pathways through predictor to mediator (a), mediator to predicted (b) and predictor to predicted (c for direct effect and c for total effect). 
Besides, self-enhancing humour had a mediator role in the relationship between $\mathrm{D}$ domain and psychological wellbeing in this study. This relationship can be understood by a close look at the D domain's premises. As Young et al. (4) indicate, D domain consists of problems with secure attachment and having no or low stability, safety or love in their lives. When individuals feel disconnected or alienated, they might feel distanced and might not think they have a place in society. However if the person competes with the thoughts of alienation and disconnection, and engage in social interaction regardless of his/her fears, at the end of several trials, he/she may find a and also feel in harmony with the others (i.e. increased psychological wellbeing) (19); eventually, this might lead to an increase in the psychological wellbeing and a reduction in the effect of disconnection related thoughts. In this relationship, self-enhancing humour might act as a band-aid which may allow the individuals not to alienate or isolate themselves and help them to maintain the contact which is necessary to feel contentment and harmony by its tolerance enhancing qualities. From another perspective (28), it is known that positive humour use can help individuals at achieving higher levels of positive emotions and help them at reassigning the coping methods that they use; specifically, the reappraisal of the current negative state. Through positively aligned behaviour and attitude change, individuals might increase their psychological wellbeing effectively. To note, the compensatory type of mediation also indicates that self-enhancing humour does not solely mediate that relationship (24). Interpersonal relationships may not solely depend on one partner's endeavour and in line with that, other individuals' social behaviours might also affect this mediational paradigm, therefore the role of other variables can be examined to understand the relationships between prospective mediators.

Moreover, the mediation analyses showed that selfdefeating humour mediated the relationship between US and psychological wellbeing. The type of mediation was indirect-only and this indicates that self-defeating humour is sufficient to explain the mediational role of itself in relation to EMSs and psychological wellbeing (24). Self-defeating humour can be inferred as schema surrender type of coping for US domain schemas since Young et al. (4) state that these individuals usually have high standards, rigid rules and are perfectionists; in terms of schematic conditions, they express hypercriticalness toward oneself. Hypercriticalness and negative thoughts about one's inadequacy might lead to complete surrender of schema and one might engage in self-defeating humour style to not to face the presumed rejection from the others and turn intrapersonal negativity into pity for one's self. In another study (26), the negative effect of selfdefeating humour inflated the loss of subjective sense of wellbeing along with lack of social support.

Furthermore, mediation analyses showed that selfdefeating humour is an indirect-only mediator which mediates the relationship between OD and psychological wellbeing. The type of mediation suggested that self-defeating humour may explain the mediational relationship and it can be the sole mediator in this relationship (24). To explore the role of the mediator it is wiser to have a look at the Turkish form of YSQ (3). In the Turkish form of schema questionnaire (9) OD domain includes selfsacrifice and punitiveness schemas. These two schemas include harsh reactions and individuals create difficult conditions for themselves to make the others feel satisfied or to punish themselves for being imperfect (4). Self-defeating humour can act similar to a schema surrender type of coping when one may consider the social situations which US schemas activated. One can accept the inadequacy and contribute for the others wellness (e.g. happiness) however this might also lead a decrement in one's sense of self-worth and eventually, psychological wellbeing.

Lastly, in the mediation analyses, it was found that self-enhancing humour mediated the relationship between IL and psychological wellbeing. Young et al. (4) suggest that individuals with dominant IL schemas tend to act more entitled, grandiose and preoccupied with thoughts of superiority. In combination with self-enhancing humour, one might use this humour style to not to face with the opposite thoughts that might correct the exaggerated views over one's self similar to schema avoidance. The individuals might feel unique, useful and praised by the others and this would contribute their psychological wellbeing positively (19). The type of mediation was indirect only therefore it can be stated that self-enhancing humour was able to explain the 
mediational paradigm as the only mediator (24).

Recent study's findings emphasize that both the EMSs and the use of humour can affect the one's ability to live a meaningful, harmonious, productive and happy life. Moreover, the study shows that these effects can be either adaptive or maladaptive, and the unique interactions between EMSs and the humour styles can play a unique role which might contribute the one's psychological wellbeing in both positive and negative ways. The psychological wellbeing is plastic, can be altered via behaviour change (29) and humour can be a medium for reaching different states of psychological wellbeing (4). The current study's findings suggest that the negative effects of EMSs on the individuals' psychological health can be altered positively or negatively by the use of specific humour styles. Specifically, the mediational roles of self-enhancing, self-defeating and aggressive humour might allow the therapists to intervene subtle mediums of self-harm (i.e. maladaptive humour) or strengthen the self-help (i.e. adaptive humour) and eventually lead individuals to reach elevated states of psychological wellbeing. In future studies, the efficacy of humour as a medium might be inquired and practical uses in therapeutic and social environments can be explored. In and out session use of humour and its effects on the client's psychological wellbeing can be examined. As the complementary mediations of the study indicate, the other prospective mediators (e.g. intelligence, personality types, inter-personal factors) can be investigated and the mediational paradigms can be enhanced to increase the effectiveness of the scheme.

The study bears several limitations. First of all, the participants were not selected from a clinical environment. The severity of the characteristics of schema theory may change in clinical populations therefore the use of humour and the effect of the humour styles can be different from the nonclinical population. Secondly, the sought relationships were not acquired via experimental methods, therefore, the correlational nature of the results do not imply causation and may only allow us to make inferences on the nature of the relationship between types of humour, EMSs and psychological wellbeing. Experimental or quasi-experimental models may increase the power of the causal infer- ences and clinical trials might show the subjective power of the humour in both inter and intrapersonal issues. Alternatively, to diminish the limitations of cross-sectional studies (i.e. limited time series data) such methods like Temporal BootStrap (TBS) and other statistical corrections can be applied in future studies with appropriate adjustments in data collection and screening (30). Lastly, in the IA and D domains, the significant mediations were complementary, suggesting that there is a likelihood of other possible mediators as stated in Zhao, Lynch, and Chen (24). Therefore, in the future studies including other possible variables into the theoretical framework would be more beneficial.

Correspondence address: Assoc. Prof., Bahçeşehir University, Psychology Department, Istanbul, Turkey turkuleraka@gmail.com 


\section{REFERENCES}

1. Beck AT, Alford BA. Depression: Causes and treatment (2nd ed.). Philadelphia: University of Pennsylvania Press, 2009.

2. Young JE. Cognitive therapy for personality disorders. Sarasota, FL: Professional Resources Press, 1990.

3.Young JE. Cognitive therapy for personality disorders: a schema-focused approach. Sarasota, Florida: Professional Resource Press, 2003.

4. Young JE, Klosko JS, Weishaar, M.E. Schema therapy: A practitioner's guide. New York-London: The Guilford Press, 2003.

5. Young JE, Rygh JL, Weinberger AD, Beck AT. Cognitive therapy for depression. New York: The Guilford Press, 2008.

6. Lobbestael J, Arntz A. Cognitive contributions to personality disorders. New York, NY: Oxford University Press, 2012.

7. Bowlby J. The making and breaking of affectional bonds. Br J Psychiatry 1977; 130: 201-210.

8. Mącik D, Chodkiewicz J, Bielicka D. Trans-generational transfer of early maladaptive schemas - a preliminary study performed on a non-clinical group. CIPP 2016; 4: 132-145.

9. Soygüt GT, Karaosmanoğlu AT, Çakır ZT. Erken dönem uyumsuz şemaların değerlendirilmesi: Young şema ölçeği kısa form-3'ün psikometrik özelliklerine ilişkin Bir inceleme. Turk Psikiyatri Derg 2009; 20: 75-84.

10. Young JE. Young Schema Questionnaire - Short Form 3 (YSQ-S3). New York, NY: Cognitive Therapy Center, 2005.

11. Rezaei M, Ghazanfari F, Rezaee, F. The role of childhood trauma, early maladaptive schemas, emotional schemas and experimental avoidance on depression: A structural equation modeling. Psychiatry Res. 2016; 246: 407-414.

12. Dozois DJA, Martin RA, Bieling PJ. Early maladaptive schemas and adaptive/maladaptive styles of humor. Cognit Ther Res 2009; 33: 585-596.

13. Dozois DJA, Martin RA, Faulkner B. Early maladaptive schemas, styles of humor and aggression. Humor 2013; 26: 97 116.

14. Martin RA. The psychology of humor: An integrative approach. Burlington, MA: Academic Press, 2007.

15. Martin RA, Puhlik-Doris P, Larsen G, Gray J, Weir K. Individual differences in uses of humor and their relation to psychological well-being: Development of the humor styles questionnaire. J Res Pers 2003: 3748-3775.

16. Saroglou V., Scariot C. Humor styles questionnaire: Personality and educational correlates in Belgian high school and college students. Eur J Pers 2002; 16: 43-54.

17. Saroglou V, Lacour C, Demeure M. Bad humor, bad marriage: Humor styles in divorced and married couples. Eur $\mathbf{J}$ Psychol 2010; 3: 94-121.

18. Saroglou V. Being religious implies being different in humour: Evidence from self and peer-ratings. Ment Health Relig Cult 2004; 7: 255-267.

19. Tennant R, Hiller L, Fishwick R, Platt S, Joseph S, Weich S, Parkinson J, Secker J, Stewart-Brown S. The Warwick-
Edinburgh mental well-Being scale (WEMWBS): Development and UK validation. Health Qual Life Outcomes 2007; 5: 50-63.

20. Yerlikaya EE. Mizah Tarzları Ölçeği'nin (The Humour Styles Quesionnaire) uyarlama çalışması. Çukurova Üniversitesi, Unpublished master's thesis 2003.

21. Keldal G. Warwick-Edinburgh mental iyi oluş ölçeği'nin Türkçe formu: Geçerlik ve güvenirlik çalışması. JHSOAA 2015; 3: $103-115$

22. Hayes AF. Methodology in the social sciences. Introduction to mediation, moderation, and conditional process analysis: A regression-based approach. Guilford Press 2013.

23. Hayes AF, Rockwood NJ. Regression-based statistical mediation and moderation analysis in clinical research: Observations, recommendations, and implementation. Behav Res Ther 2017; 98: 39-57.

24. Zhao X, Lynch JR JG, Chen Q. Reconsidering Baron and Kenny: myths and truths about mediation anal ysis. J Consum Res 2010; 37: 197-206.

25. Kazarian SS, Martin, RA. Humour styles, personality, and well-being among Lebanese university students. Eur J Pers 2004; 18: 209-219.

26. Bos EH, Snippe E, de Jonge P, Jeronimus BF. Preserving subjective wellbeing in the face of psychopathology: buffering effects of personal strengths and resources. PLoS One 2016; 11: e0150867.

27. Askari I. Early Maladaptive Schemas and CognitiveBehavioral Aspect of Anger: Schema Model Perspective. J Ration Emot Cogn Behav Ther. 2019; 37:262-283.

28. Puente-Martínez A, Páez D, Ubillos-Landa S, Da CostaDutra S. Examining the structure of negative affect regulation and its association with hedonic and psychological wellbeing. Front. Psychol 2018; 9.1592.

29. Weiss LA, Westerhof GJ, Bohlmeijer ET. Can we increase psychological well-being? The effects of interventions on psychological well-being: A meta-Analysis of randomized controlled trials. PLoS One 2016; 11: 1-16.

30. Tucker A, Li Y, Garway-Heath D. Updating Markov models to integrate cross-sectional and longitudinal studies. Artif Intell Med 2017; 77: 23-30. 